\title{
ONE HUNDRED SHERDS OF GREY: COMPOSITIONAL AND TECHNOLOGICAL CHARACTERIZATION OF MEDIEVAL GREYWARE POTTERY PRODUCTION AT CABRERA D'ANOIA, CATALONIA, SPAIN
}

\author{
E. TRAVÉ ALLEPUZ ${ }^{1,2 *}$, P. S. QUINN¹, M. D. LÓPEZ PÉREZ ${ }^{2}$ and J. I. PADILLA LAPUENTE $(\dagger)^{2}$ \\ ${ }^{1}$ Institute of Archaeology, University College London, 31-34 Gordon Square, London, WC1H 0PY, United Kingdom. \\ ${ }^{2}$ Medieval and Post-medieval Research Group; Department of Medieval History, Paleography and Diplomatics, \\ University of Barcelona, Montalegre 6, 08001, Barcelona, Spain.
}

*e.allepuz@ucl.ac.uk

\begin{abstract}
Detailed petrographic and geochemical analysis of 100 sherds of greyware cooking pottery from the large Medieval kiln site of Cabrera D'Anoia has revealed the presence of several compositional groups that are correlated to different phases in the operation of the site. These appear to relate to changes in the extraction of local raw materials for pottery production, concomitant with the development of the workshop over several centuries. Macroscopic, microstructural and mineralogical analyses have permitted the reconstruction of a consistent tradition of ceramic manufacture at Cabrera D'Anoia. Close correspondence between the petrographic and geochemical characterisation of the sherds provides several well-defined compositional reference groups for this major production centre. This is permitting the identification of the products of Cabrera D'Anoia at other rural sites in Catalonia and will provide a firm basis with which to examine the supply and demand of utilitarian pottery vessels in this area during the Medieval period.
\end{abstract}

KEYWORDS: Medieval Pottery, Petrography, Geochemistry, Kiln-Site, Catalonia, Spain

\section{INTRODUCTION}

Sherds of plain greyware cooking vessels are one of the most frequent artefacts excavated from Medieval sites in Catalonia (González 1997) and the wider region of northern Iberia (Bohigas and Gutiérrez 1989) (Fig. 1). Despite their abundance and homogeneous appearance, these utilitarian pots may hold significant potential for studying the traditions of Medieval Catalonian craft production and their organisation, as well as for mapping patterns of trade and exchange between rural communities that were the main consumers of greyware pottery.

Several ancient production centres of greyware pottery are known in Catalonia, some of which have been excavated. The largest of these is Cabrera D'Anoia, located $70 \mathrm{~km}$ from the city of Barcelona (Fig. 2). This site, which consists of thirty or more kilns and four workshops, produced greyware cooking pottery between the 10-14th centuries AD. It was clearly a major supplier of utilitarian ceramics to settlements in the region and is therefore a good place to start in order to understand the processes of Medieval greyware production and distribution.

As part of a larger project focussed on the development and operation of Cabrera D'Anoia, we have studied 100 sherds of greyware pottery in detail, with the aim of reconstructing aspects of their manufacture at the site and establishing characteristics that may enable the products of this workshop to be identified at other locations in Catalonia. Given the high level of macroscopic homogeneity displayed by the many thousand sherds that have been excavated from Cabrera D'Anoia, as well as those from other greyware production sites, we have focussed on their petrographic, geochemical and microstructural composition in order to characterise the products of this workshop and detect any changes in raw materials and technology over time. Previous analytical studies on greywares from Catalonia (Pradell et al. 1991; Vendrell et al. 1997a; 1997b) have demonstrated the value of this approach. However, a considerable gap exists in the knowledge of this common group of pottery.

Our research reveals that Medieval greyware pottery manufactured at Cabrera D'Anoia has several distinctive compositional signatures that relates to the specific local geological environment of the site. This was exploited not only as a raw material for ceramic production, but also to accommodate the development and expansion of the workshop over time. For several centuries, Cabrera D'Anoia produced a highly standardised product that appears to have had a sizeable market in the surrounding rural landscape. Despite their homogeneity, sherds excavated from different phases of the site exhibit compositional differences at the microscopic and elemental level, that may relate to changes in clay procurement or perhaps manufacturing technology during the operation of the workshop.

\section{STUDY SITE AND SAMPLES}

The pottery production centre of Cabrera D'Anoia was excavated during five fieldwork campaigns that took place between 1986 and 1990 (Leenhardt et al. 1995; Padilla and Vila 1998). This revealed a large number of kilns and several workshop areas that had been cut into the rocky hillside on which the site is located (Fig. 3a). The potters exploited the natural geological configuration of the landscape, which consists of a hard travertine platform overlying 
softer, weathered granodiorite (Figs. $3 \mathrm{~b}$ to $3 \mathrm{e}$ ). Kilns were located in the open air, forming rows close to natural shelters formed in the granodiorite layer below the travertine ceiling. The shelters were intentionally enlarged by potters to provide a workshop area for paste preparation and vessel forming (Figs. 3c and 3d).

In the workshop areas certain elements related to the daily use of the site were encountered, such as small travertine slabs and percussive tools for paste preparation, rows of postholes that supported drying structures, and occasionally circular pits or silos that might have been used for water or clay storage. Distinctive concentric patches of clay suggest that pottery shaping may have taken place near the mouth of the shelters.

Firing was carried out in double-chambered kilns (Fig. 4). The fire chamber and access hole were cut into the granitic bedrock leaving a pierced platform separating on which the pottery was placed. Though all the kilns at Cabrera D'Anoia had collapsed by the time of excavation, it is thought they had a c. 1 m cylindrical adobe wall with a domed roof, constructed above the firing chamber. This kiln design is common in Medieval Catalonia and has also been excavated at the site of Casampons, located $90 \mathrm{~km}$ from Cabrera D'Anoia (Fig. 2) (Padilla 1984).

As the kilns neared the end of their use life or the travertine ceiling of the workshop areas collapsed (Fig. 3e), new spaces were excavated immediately adjacent to these or further into the cliff (Fig. 3a). As many as 30 kilns and four workshop areas were created in this way at Cabrera D'Anoia. These can be attributed to several phases of operation of the site. Kiln wasters were dumped into unused kilns once they had been abandoned. Excavation of the site suggests that wasters were deposited on a regular basis in the closest unused kiln, usually on the left or behind the current working area.

The continuous interaction between the manufacturing activities of the potters and the natural rocky landscape that took place at Medieval Cabrera D'Anoia is a good example of the 'Cave-Dwelling Production System' (Amouric et al. 1995). This model, which was proposed to describe the production of several pottery workshops in Southern France, is highly appropriate to the development of the site and its relationship to the natural environment (Travé 2009).

As part of a reassessment of the previously excavated material from Cabrera D'Anoia (Padilla et al. 2008, 2011a, b), 5000 waster sherds were studied macroscopically (Travé 2009). This suggests that as much as 95\% of the vessels produced at the site in Medieval times were a type of spherical boiling pot with a diameter of c. $20 \mathrm{~cm}$, referred to as an olla (Figs. 1a to 1e). Other forms such as casseroles (Fig. 1f), wash basins (Fig. 1k) and water jars (Fig. 1g and 1j) were also represented in the studied sherds, but occur in much smaller proportions, reaching no more than $5 \%$ of the waster sherds. Given the dominance of cooking pots, Cabrera D'Anoia can be classified as an ollería or cooking-pot producing centre. Most of the vessels exhibit incised decoration with simple motives of straight horizontal lines, short vertical incisions, crosses, and occasionally undulose lines (Travé 2009, 233-247).

The waster sherds appear to have been discarded for a variety of reasons. Some were over-fired and exhibit signs of bloating whereas others may have broken due to the collapse of the kiln load or the kiln structure itself. It appears that the kilns at Cabrera D'Anoia were used until the roof fell in, which in some cases may have been during a firing.

For the purpose of detailed compositional and microstructural characterisation, we selected 100 samples from the 5000 sherds that were studied macroscopically. These were taken from excavated kilns of Phase 2 (12th century AD), Phase 4 (mid 13th century AD), Phase 6a (late 13th century AD) and Phase 6b of the site (mid 14th century AD) (Fig. 3 (a)), in order to obtain a representative sample of the workshop's production over time. Phases 1 and 5 of Cabrera D'Anoia are poorly represented and contain little or no ceramic material for analysis. Phase 3 of the site, which corresponds to early 13th century AD activity, was unfortunately destroyed during the building of a nearby road. The 100 samples selected for detailed analysis were mostly olla fragments, but also contained sherds from three casseroles (samples CA18, CA19 and CA33).

\section{ANALYTICAL METHODS}

All 100 selected greyware pottery samples were analysed using a combination of thin section petrography, X-ray fluorescence spectrometry (XRF) and X-ray diffraction (XRD). All three methods of analysis were performed independently and the results were then compared with one another as well as with the accompanying archaeological information on the sherds. Standard $30 \mu \mathrm{m}$ thin sections of al sherds were visually grouped into petrographic fabrics under the polarising light microscope based upon the nature of their inclusions, clay matrix and voids (Quinn 2013, 7379). Each fabric was then interpreted in terms of its raw materials and manufacturing technology. Possible sources of raw materials for the production of the ceramics of the petrographic fabrics were identified using geological maps of the area.

Geochemical characterisation was carried out by the Material Culture and Archaeometry Research Group (ArqUB) at the Laboratories of Scientific and Technical Services, University of Barcelona, using a Philips PW 2400 wavelength dispersive XRF. Subsamples c. $10 \mathrm{~g}$ in weight were taken from each sherd for the purpose of XRF analysis. The surface layer of each subsample was removed with a tungsten carbide abrasive tool and the remaining material was then ground to a fine powder and oven dried at $105^{\circ} \mathrm{C}$. The dried powder was prepared as fused beads for major and minor elements, using $0.3 \mathrm{~g}$ of sample and $5.7 \mathrm{~g}$ of lithium tetraborate. For $\mathrm{Na}$ and trace elements, c. $5 \mathrm{~g}$ of ground powder $(>80 \mu \mathrm{m})$ 
was pressed as pellets using $2 \mathrm{ml}$ of a synthetic resin. A total of 29 major, minor and trace elements ( $\mathrm{Al}, \mathrm{Ba}, \mathrm{Ca}, \mathrm{Ce}, \mathrm{Co}$, $\mathrm{Cr}, \mathrm{Cu}, \mathrm{Fe}, \mathrm{Ga}, \mathrm{K}, \mathrm{Mg}, \mathrm{Mn}, \mathrm{Mo}, \mathrm{Na}, \mathrm{Nb}, \mathrm{Ni}, \mathrm{P}, \mathrm{Pb}, \mathrm{Rb}, \mathrm{Si}, \mathrm{Sn}, \mathrm{Sr}$, Th, Ti, V, W, Y, Zn, Zr) were analysed as oxides using an in-house calibration program and expressed as percentage weight (\%wt) or parts per million (ppm). By also running standard reference materials of known concentration, the accuracy of the XRF analysis was determined to be c. $98 \%$ for major elements and c. $95 \%$ for minor and trace elements. The trace elements Co and V were measured with a lower accuracy of $89 \%$ and $86 \%$ respectively.

The elemental data obtained by XRF was normalised by log transforming each element relative to $\mathrm{Al}_{2} \mathrm{O}_{3}$ to account for the large differences in the concentrations of the major and trace elements that could have affected the subsequent statistical classification. The log-transformed multivariate data was then analysed via hierarchical cluster analysis (HCA) and principle components analysis (PCA) in order to identify compositional patterning and the existence of geochemical groups. The elements $\mathrm{Sn}$ and Mo were left out of the statistical classification due to their very low concentration. In addition, $\mathrm{W}$ and Co were omitted due to their potential enrichment by the tungsten tool used in sample preparation.

The mineral phases present in the ceramic samples were determined using a Siemens D-500 XRD machine also at ArqUB. Powered samples of $1 \mathrm{~g}$ in weight were prepared as described above and analysed using $\mathrm{Cu}-\alpha$ radiation $(\lambda=1.5406 \AA)$, with a graphite diffracted beam monochromator and a power of $1.2 \mathrm{~kW}(40 \mathrm{kV}, 30 \mathrm{~mA})$. The XRD results were used to identify the types of clay minerals present in the raw materials used to manufacture the pottery. The presence of specific mineral phases was also used to interpret the temperatures to which the ceramics were subjected during firing.

\section{COMPOSITIONAL CLASSIFICATION}

Thin section petrographic analysis revealed the presence of four main related fabrics among the 100 greyware sherds analysed from Cabrera D'Anoia (Table 1) (Fig. 5). Samples classified within the 'Coarse Granitic Fabric' (Figs. 5a and $5 b)$ are characterised by relatively coarse (silt to coarse sand sized), generally angular, inclusions derived from 'granitic' acid igneous rock, within a non-calcareous clay matrix. These include quartz, polycrystalline quartz, weathered plagioclase and alkali feldspar, biotite and small intact rock fragments composed of two or more of these minerals. Small amounts of other types of inclusions, such as phyllite, calcite and sandstone are present in some samples of this fabric. The Coarse Granitic Fabric is the most common petrographic composition, accounting for $66 \%$ of the analysed samples (Table 1). It occurs in Phase 4 (mid 13th century AD) and Phase 6b (mid 14th century AD) of the site, where it is the dominant greyware fabric. It is also present in Phase 6a (late 13th century AD), but is less common in the samples analysed.

Samples of the 'Fine Granitic Fabric' (Fig. 5c) have a similar petrographic composition to the dominant Coarse Granitic Fabric, but contain finer-grained (silt to very fine sand sized) and less abundant inclusions, as well as fewer voids. This fabric accounts for only $6 \%$ of the 100 greyware samples in this study and occurs almost exclusively in Phase 2 (12th century AD) of Cabrera D'Anoia, where it is the dominant composition among the samples analysed (Table 1).

The 'Coarse Granitic with Clay Pellets Fabric' and the 'Coarse Granitic with Calcite Fabric' are coarse-textured and related to the dominant Coarse Granitic Fabric, but have been defined based upon the significant presence of other inclusions. The Coarse Granitic with Clay Pellets Fabric (Fig. 5d) is characterised by granite-derived inclusions and distinctive clay-rich inclusions, as well as other textural features. Samples of the Coarse Granitic with Calcite Fabric (Fig. 5e) contain 15-30\% micritic and sparry calcite within the inclusions, in addition to the granitic material that is present in all greyware samples. The Coarse Granitic with Clay Pellets Fabric and the Coarse Granitic with Calcite Fabric constitute $22 \%$ and $11 \%$ of the 100 analysed samples respectively. Both fabrics are common in Phase 6a (late 13th century AD) of Cabrera D'Anoia, but also occur infrequently in the Phase 6b (mid 14th century AD) material analysed (Table 1).

Hierarchical cluster analysis of the multivariate elemental data obtained by XRF revealed the presence of three main geochemical groups within the pottery sherds from Cabrera D'Anoia (Fig. 6). The three groups are also visible in a scattergram of the first two principal components of the PCA (Fig. 7a), which together account for $72 \%$ of the variance in the dataset. A scatterplot of the abundance of the elements $\mathrm{CaO}$ against $\mathrm{NiO}$ (Fig. 7c) also reveals the same three geochemical groups that are present in the PCA and cluster analysis. Sherds belonging to geochemical Group 1 are characterised by $<3 \% \mathrm{CaO}$, whereas the Group 2 samples have c. 2-10\% $\mathrm{CaO}$ content. Chemical Group 3 has low $\mathrm{CaO}$ $(<1 \%)$ and higher $\mathrm{Ni}(>40 \mathrm{ppm})$ and $\mathrm{Fe}_{2} \mathrm{O}_{3}(>6 \%)$ compared to the other two groups.

The three geochemical groups correspond well to the main phases of operation at Cabrera D'Anoia (Table 1) (Fig. 6). Samples belonging to Group 1, which accounts for $46 \%$ of the analysed sherds, come mainly from Phase 4 (mid 13 th century AD) and Phase $6 \mathrm{~b}$ (mid 14th century AD), but also occur in smaller numbers in the Phase 6a (late 13th century AD) material analysed. Chemical Group 2 accounts for $38 \%$ of the samples and is restricted to Phase 6 a (late 13 th century AD) and Phase $6 \mathrm{~b}$ (mid 14th century AD). Lastly, all five samples belonging to Group 3 come from the second phase (12th century AD) of operation of the workshop. 
A comparison of the petrographic and geochemical classification of the greyware sherds from Cabrera D'Anoia (Table 1) (Figs. 6, 7b and 7c) reveals that they correspond well with one another. The dominant Coarse Granitic Fabric equates more of less to the large geochemical Group 1, although a few Coarse Granitic Fabric samples were classified in Group 2. Petrographic variation detected in the Coarse Granitic Fabric in terms of the presence/absence of certain non-granite inclusions may explain the heterogeneity displayed in geochemical Group 1 in the dendrogram and scatterplots (Figs. 6 and $7 \mathrm{~d})$.

All sherds of the Coarse Granitic with Clay Pellets Fabric and the Coarse Granitic with Calcite Fabric that could be classified geochemically, are contained within Group 2. In the dendrogram in Fig. 6 and the scatterplot in Fig. 7d, a broad split is visible in Group 2, which equates to these two related petrographic fabrics. The most striking correspondence between the results of the petrographic and geochemical classification of the greyware samples from Cabrera D'Anoia is the clear separation of all but one of the Fine Granitic Fabric sherds into geochemical Group 3 (Figs. 6 and 7d).

Approximately 11 of the 100 analysed samples could not be assigned to one of the three identified geochemical groups in the cluster analysis (Fig. 6). Nevertheless, in the scatterplot of principal components 1 and 2 (Fig. 7b) many of these are situated alongside classified samples with which they are petrographically related. The classification of a single Fine Granitic Fabric sample in geochemical Group 1 and a Coarse Granitic Fabric sample alongside the Fine Granitic Fabric samples of geochemical Group 3 are difficult to explain. Notwithstanding these discrepancies, the close correspondence of the petrographic and the geochemical classification of the 100 greyware sherds from Cabrera D'Anoia, as well as their correlation with different phases in the operation of the workshop suggest that these groups are likely to be archaeologically meaningful.

X-ray diffraction analysis reveals that illite is the dominant clay mineral phase in most of the 100 ceramic samples analysed from Cabrera D'Anoia. Few differences in clay mineralogy were present between the samples of the petrographic and geochemical groups described above. However, mineralogical differences between samples from the same compositional groups were detected. These may be related to their firing technology and are discussed below.

\section{RAW MATERIALS}

The ceramic raw materials used to manufacture greyware pottery at Cabrera D'Anoia are likely to have been procured locally. The site is situated at the edge of a granodiorite outcrop (Fig. 8), which weathers to form natural shelters that were modified by the potters (Fig. 3 (b) to (d)). The angular, poorly-sorted nature of the granitic inclusions within the three main coarse fabric groups (Fig. 5) might suggest that they could have derived from a residual clay source formed on granodiorite bedrock. However, small quantities of other seemingly naturally occurring inclusions such as phyllite, calcite and sandstone are also present within the ceramics. As these cannot be attributed to a granodiorite source, it is unlikely that the utilised clay formed directly upon the local igneous outcrop. The River Anoia, which passes close to the site (Fig. 8), is located in a steep valley cut into granodiorite bedrock. Local alluvial deposits associated with this river might be expected to contain a high proportion of minimally transported granodiorite clasts, as well as travertine, sandstone and low-grade metamorphic material derived from further upstream or within the catchment of nearby tributaries (Fig. 8). With this in mind it is possible that overbank clay deposits of the river Anoia were exploited as a raw material for greyware pottery production. Unfortunately, significant modern development has taken place along this stretch of the river and the mapped alluvial deposits (Fig. 8) were therefore not accessible for detailed analysis.

Experimental studies on the influence of specific types of inclusions on the heating effectiveness of ceramics (Hein et al. 2008) have shown that a moderate proportion (20-30\%) of granite inclusions can increase the thermal conductivity of earthenware pastes and may thus be beneficial for the performance of cooking vessels. With this in mind, it is possible that the potters of Cabrera D'Anoia selected a clay source with naturally occurring granitic inclusions in order to produce ollas with high heating effectiveness. However, a small but significant proportion of phyllite inclusions also occur in some of the analysed greyware samples. In contrast to granite, inclusions of phyllite may reduce the thermal conductivity of ceramic pastes due to their platy shape (Hein et al. 2008).

The occurrence of several related greyware fabrics/chemical groups at Cabrera D'Anoia may indicate the extraction of clay from different locations within the local alluvium. It is likely that these deposits contain natural compositional and textural variation, although the nature of this is yet to be determined. This variation could account for the compositional groups of pottery detected in this study. The close relationship between the petrographic fabrics/geochemical groups and the analysed phases of Cabrera D'Anoia might therefore suggest that raw material exploitation strategies changed over time. An alternative explanation is that potters modified a single clay source via processes such as refining or tempering. This is discussed below.

\section{MANUFACTURING TECHNOLOGY}

The generally poorly-sorted, unimodal nature of the granitic mineral and rock inclusions in the majority of the greyware sherds analysed from Cabrera D'Anoia suggests that they were natural components of the clay source used to manufacture these ceramics. The less frequent micritic calcite, sandstone and phyllite inclusions that occur in several of the detected fabrics do not differ in shape or size from the granite derived inclusions and are also suspected to have been 
naturally occurring within an alluvial clay source rather than being added as temper. An exception might be the significant component of micritic and sparry calcite inclusions within the sherds of the Coarse Granitic with Calcite Fabric. Though it is not possible to rule out the possibility that these were an intentional addition, the irregular occurrence of small quantities of similar inclusions in the other two coarse fabrics suggests that they were intrinsic in origin.

The coarse, sandy texture of the inclusions in most fabric groups suggests that the utilised clay source was not refined. An exception might be the ceramics of the Fine Granitic Fabric/Geochemical Group 3, which are characterised by finer, silt-sized inclusions. The petrographic similarity between these samples and the Coarse Granitic Fabric might suggest that they were made by modifying a similar coarse clay source, by means of sieving or levigation. The statistical classification of the XRF data reveals that samples of the Fine Granitic Fabric are geochemically distinct from the Coarse Granitic Fabric/Geochemical Group 3 (Figs. 6 and 7). They exhibit lower concentrations of $\mathrm{SiO}_{2}$ and $\mathrm{CaO}$ and higher percentages of $\mathrm{Ce}, \mathrm{Cu}, \mathrm{Pb}, \mathrm{Ti}$ and $\mathrm{Zn}$ (Table 2). It has been suggested that the process of refining clay can alter the chemical composition of ceramics (e.g., Kilikoglou et al. 1988) and the removal of the silica-rich granite-derived inclusions and the rare limestone fragments of the Coarse Granitic Fabric might therefore account for the different chemical composition of the Fine Granitic Fabric/Geochemical Group 3. However, these differences could also have occurred due to the exploitation of a finer clay bed within the same or a different alluvial deposit during Phase 2 of Cabrera D'Anoia. In the absence of field samples and experimental studies it is not possible to distinguish between these possibilities.

Clay rich, plastic inclusions occur in small amounts in most analysed samples. These are likely to be naturally occurring, iron-rich clay pellets of the type that can be found in many sedimentary deposits and particularly soil. However, the Coarse Granitic with Clay Pellets Fabric contains a greater proportion of clay rich inclusions and textural features that may be evidence for the intentional blending of two different clay sources (Fig. 5d). These conspicuous phenomena are dark red in colour with high optical density and range from well defined equant bodies to streaks and swirls with merging boundaries (Whitbread 1986). They could have been produced by the addition of finer, iron-rich clay to the common coarse, sandy material used for the Coarse Granitic Fabric and the Coarse Granitic with Calcite Fabric. However, similar heterogeneity can occur in natural clay sources due to sedimentary processes or bioturbation, and distinguishing this from intentional clay mixing can be difficult (Quinn 2013, 168).

The greyware ollas and casseroles analysed from Cabrera D'Anoia appear to have been hand-built by means of applying coils of clay to a moulded base. In thin section, several samples exhibit a broadly concentric arrangement of inclusions that are interpreted as relic coils or ropes of clay (Fig. 5f) (Quinn 2013, 177) that were not fully obliterated by secondary forming. The rough coil-built vessels appear to have been thinned by rotating them on a slow wheel or 'tournette'. This gave them a smooth finish on their interior and exterior surfaces and resulted in the alignment of elongate inclusions close to the vessel surface in thin section.

Most sherds have a grey colour in hand specimen and in thin section that is suggestive of firing in a neutral to reducing atmosphere. Some are lighter and more oxidised or show core-margin colour differentiation. The clay matrix of most samples appears to be slightly optically active to optically inactive, suggesting an equivalent firing temperature of c. $850^{\circ} \mathrm{C}$ (Reedy 2008,186 ), though the birefringence of the clay matrix can be difficult to observe within reduction fired ceramics (Quinn 2013, 191). The occurrence of primary calcite inclusions in numerous greyware samples, particularly those of the Coarse Granitic with Calcite Fabric, might be taken to indicate a firing temperature of below c. $900^{\circ} \mathrm{C}$ (Rice $1987,97-98$ ). X-ray diffraction analysis reveals the presence of significant illite in the majority of the analysed samples (Fig. 9a). This clay mineral is stable up to a temperature of c. $800^{\circ} \mathrm{C}$ during the firing of ceramics under reducing conditions (Maritan 2004). Its absence in several samples belonging to the main petrographic and geochemical groups (Fig. 9b), suggest that they were fired to a temperature of $850^{\circ} \mathrm{C}$ or more. Several of these samples contain high temperature mineral phases such as hercynite and spinel that form above c. $900^{\circ} \mathrm{C}$ in reducing conditions (Fig. 9b) (Maritan 2004). Some of the waster sherds that have been analysed exhibit bloating and failure due to overfiring.

The simple updraft double-chambered kilns used at Cabrera D'Anoia (Fig. 4) were capable of achieving a temperature of c. $800^{\circ} \mathrm{C}$ necessary to produce coarse unglazed earthenware pottery. The higher temperatures experienced by some sherds suggests local variation within the kiln that could have been caused by drafts or the placement of the individual pottery vessels. It is likely that a reducing atmosphere was achieved by closing the structure at the end of the firing, though this did not always ensure fully reducing conditions, as indicated by the presence of some lighter coloured, more oxidised sherds in the samples analysed.

\section{DISCUSSION}

For several centuries, the Medieval olleria at Cabrera D'Anoia mass produced grey coarseware cooking pots that were morphologically very consistent both in terms of their form and size. The petrographic and geochemical analysis of a selection of 100 ollas and other utilitarian vessels in this study reveals that the ceramic products of this large rural workshop also exhibit significant continuity in raw material selection and manufacturing technology.

The potters working at Cabrera D'Anoia appear to have obtained relatively coarse, juvenile alluvial clay with abundant granitic clasts from the nearby River Anoia and may have used this material without significant modification to produce 
greyware pottery at the site. Ollas and other vessel forms were constructed by moulding and coil building, leaving characteristic traces within the sherds in thin section. Circular features discovered inside the collapsed caves at Cabrera D'Anoia suggest that individual potters worked on a tournette. These devices may have been used to smooth and finish the rough coil-built vessel forms. Firing was performed outside the mouth of the caves in double-flued, updraft kilns cut into the rocky soil with an adobe firing chamber. Potters closed and sealed the kilns during firing to achieve an oxygenpoor atmosphere and give the pots their consistent dull grey colour. Thin section petrography and XRD analysis indicate that the vessels were fired to a temperature of c. $800^{\circ} \mathrm{C}$, which is common for unglazed earthenware pottery. However, some vessels appear to have been subjected to higher temperatures of $900^{\circ} \mathrm{C}$ or more, perhaps due to local variation within the kilns.

The pottery manufacturing sequence that can be reconstructed for the greyware ceramics of Cabrera D'Anoia by means of archaeological evidence and the macroscopic and compositional analysis of sherds provides important data with which to examine the traditions Medieval Catalonian craft production. Comparisons with other Medieval potting workshops such as Casampons, Santa Creu D'Ollers or Sant Fost de Campsentelles (Riu 1990) reveal a continuous craftsmanship with only minor variation over long periods of time. The contemporaneous Catalan kiln site of Casampons (Fig. 2), produced grey earthenware ollas that are morphologically very similar to those of Cabrera d'Anoia.

Despite the typological and compositional homogeneity of the Medieval greyware pottery from Cabrera D'Anoia, differences in their paste have been detected at the mineralogical and elemental level. These compositional groups, which are confirmed by the close correspondence between the results of the petrographic and geochemical classification of the 100 sherds, are broadly correlated with the different phases of the workshop. For example ceramics produced during the second phase of the site (12th century AD) were made of a finer paste that is geochemically distinguishable from those made in the later phases, and pottery analysed from the fourth phase of the site are characterised by a single coarse petrographic and geochemical composition. These chronological patterns in ceramic composition could represent changes in ceramic raw material procurement, or perhaps the intentional modification of a single clay source over time. In the absence of field samples, it is not possible to distinguish between these possibilities. A possible scenario might be that potters obtained clay from different sites or beds within a single clay source, perhaps due to the exhaustion of suitable clay at certain locations, or in response to external factors.

The longevity of pottery production at Cabrera D'Anoia might be attributed to the favourable environmental conditions at the site (Matson 1965: 203). These included a suitable nearby source of coarse granitic clay, abundant water and available sources of fuel (Py 2001; Travé 2009, 185-198). In addition, the unique geological and geomorphological configuration of the site, specifically the existence of natural caves that could be enlarged and extended over time, is likely to have been an important factor in the establishment of a pottery workshop at Cabrera D'Anoia and its operation for several hundred years.

The mass production of a single standardised product for four centuries at Cabrera D'Anoia indicates that a consistent market for its pottery existed within the surrounding area. The size and geographic extent of this demand, as well as the mechanisms by which pottery from Cabrera D'Anoia and other greyware production sites in Catalonia were distributed, are the topics of the next stage of our research. By characterising compositionally the ceramics manufactured during different phases of Cabrera D'Anoia, we have established several 'reference groups' or 'control groups' (Fillieres et al. 1983; Day and Kilikoglou 2001) for the workshop (Table 2). This will hopefully enable us to detect its exported products in domestic contexts, and at markets or way stations between producer and consumer. Initial results suggest that Cabrera D'Anoia supplied greyware pottery to villages within a radius of up to $40 \mathrm{~km}$, where its ceramics can constitute as much as $50 \%$ of the excavated pottery assemblages (Travé et al. 2013). This type of information holds significant potential for mapping patterns of trade and exchange between rural communities in Medieval Catalonia, as well as for understanding market forces driving the supply and demand of utilitarian pottery in the region.

\section{ACKNOWLEDGMENTS}

The research presented in this paper forms part of the doctoral thesis of Esther Travé at University of Barcelona, which was supervised by José Ignacio Padilla. This thesis was funded by an FI grant from the Catalan Government (2006FI-01369). Ceramic studies are one of the main topics of the Medieval and Postmedieval Archaeology Research Group (2009SGR469) and this work was part of a larger research project on Cabrera D'Anoia funded by the Spanish Ministry of Science and Technology (HUM2007-61551-HIST) between 2006-2009.

Jaume Buxeda and Marisol Madrid of the Material Culture and Archaeometry Research Group (ArqUB), University of Barcelona, kindly assisted with the XRF and XRD analysis of the ceramics from Cabrera D'Anoia, which were performed at the Laboratories of Scientific and Technical Services. Jordi Illa helpfully prepared the ceramic thin sections and Miguel Angel Cau Ontiveros provided guidance on their analysis. Dr. Jacques Thiriot supervised archaeological fieldwork at Cabrera D’Anoia alongside Dr. Padilla, in a joint French \& Spanish team. Dr Padilla sadly passed away during the writing of this manuscript. Eskerrik asko, Iñaki. Hasta siempre.

\section{REFERENCES}


Amouric H, Thiriot J, Vayssettes, J L (1995) Ateliers en grotte: apport contrasté des sources écrites et des dones de terrain. Actas das $1^{a}$ Jornadas de Cerâmica Medieval e Pós-Medieval, métodos e resultados para o seu estudo, 263269, Tondela.

Bohigas R, Gutiérrez J A (eds.) (1989) La cerámica medieval en el norte y noroeste de la península ibérica. Aproximación a su studio. Universidad de León, León.

Day P, Kilikoglou V (2001) Analysis of Ceramics from the Kiln, in A LM IA Ceramic Kiln, in South-central Crete: Function and Pottery Production. (Shaw, J.W., A. Van de Moortel, P. Day, V. Kilikoglou), Hesperia Supplement 30: 111-134, Princeton.

Fillieres D, Harbottle G, Sayre E V (1983) Neutron-Activation Study of Figurines, Pottery, and Workshop Materials from the Athenian Agora, Greece. Journal of Field Archaeology 10: 55-69.

González A (ed.) (1997) Ceràmica catalana. El monument, document, Quaderns científics i tècnics, 9, Diputació de Barcelona, Barcelona.

Hein A, Müller N S, Day P M, Kilikoglou V (2008) Thermal Conductivity of Archaeo- logical Ceramics: The Effect of Inclusions, Porosity and Firing Temperature. Thermochimica Acta 480: 35-42.

Kilikoglou V, Maniatis Y, Grimanis A P (1988) The Effect of Purification and Firing of Clays on Trace Element Provenance Studies. Archaeometry 30: 37-46.

Leenhardt M, Padilla J I, Thiriot J, (1995) Organisation spatiale de l'atelier de potiers de Cabrera d'Anoia (Catalogne). Vème colloque international sur la céramique médiévale en Méditerranée Occidentale (Rabat, 11-17 novembre 1991), 58-63, Rabat.

Maritan L (2004) Archaeometric Study of Etruscan-Padan Type Pottery from the Veneto Region: Petrographic, Mineralogical and Geochemical-Physical Characterisation. European Journal of Mineralogy 16: 297-307.

Matson F R (1965) Ceramic Ecology: An Approach to the Study of Early Cultures of the Near East, in Ceramics and Man (ed. Matson, F. R.), 202-217, Chicago.

Padilla J I (1984) Contribución al estudio de las cerámicas grises catalanas de época medieval: el taller, los hornos y la producción de Casampons. Ceràmica grisa i terrissa popular de la Catalunya Medieval. Acta Mediaevalia, annex 2 , 99-143, Barcelona.

Padilla J I, Vila J M (1998) Últimas intervenciones en el alfar medieval de Cabrera d'Anoia, Barcelona. Actas das 2 as Jornadas de Cerâmica Medieval e Pos-Medieval. Tondela (Portugal), 91-99, Tondela.

Padilla J I, Álvaro K, Travé E, (2008) Un modelo de producción en gruta: el Alfar de Cabrera d'Anoia, Barcelona. Munibe (Antropologia - Arkeologia) 59: 251-272.

Padilla J I, Álvaro K, Travé E (2011a) Las cerámicas culinarias de Cabrera d'Anoia: Estrategias de producción en un alfar medieval. Arqueología y Territorio Medieval 18: 117-144.

Padilla J I, Álvaro K, Travé E (2011b) El alfar medieval de vajilla culinaria de Cabrera d'Anoia, Territorio, Sociedad y Poder 6: 73-104.

Pradell T, Martínez-Manent S, Nogués-Carulla J M, Vendrell-Saz M (1991) Cerámica gris medieval catalana: caracterización y tecnología de producción". In Actas do IV Congreso da Cerámica Medieval no Mediterraneo Occidental, Mértola, Campo Arqueológico de Mértola, 601-610.

Py V (2001) Les potiers et la forêt a Cabrera d'Anoia (Catalogne): XIe - XIVe siècle. Anthracologie, ethnobotanique, et paléoécologie; archéologie et artisanat, Unpublished doctoral thesis, Univerity of Provence.

Quinn P S (2013) Ceramic Petrography: The Interpretation of Archaeological Pottery \& Related Artefacts in Thin Section. Archaeopress, Oxford. 
Reedy C L (2008) Thin Section Petrography of Stone and Ceramic Cultural Materials. Archetype Publications, London.

Rice P M (1987) Pottery Analysis: A sourcebook. University of Chicago Press, Chicago.

Riu M (1990) Talleres y hornos de alfareros de cerámica gris en Cataluña. Fours de potiers et "testares" médiévaux en Méditarranée Occidentale. Methodes et resultats (Eds. Bazzana, A., Amigues, F.), 105-115, Publicaciones de la Casa de Velázquez, Madrid.

Travé E. Padilla J I, Quinn P S (2013) Utilitarian Cooking Wares in Medieval Catalonia (Spain): Provenance, Technology and Trade in Rural Areas. European Meeting on Ancient Ceramics. University of Padova, Italy, 19-21 September 2013. Conference program and abstracts, (eds. Piovesan R, Maritan L, Grifa C), 68. Department of Geosciences, University of Padova.

Travé E (2009) Producció i distribució d'una terrisseria medieval: Cabrera d'Anoia, Doctoral thesis, University of Barcelona. (Published on line: http://www.tesisenxarxa.net/TDX-0112110-111917)

Vendrell-Saz M, Pradell T, García-Vallès M T, Molera J (1997a) Medieval reduced pottery in Catalonia: technology and distribution, in Santoro S, Fabri B (eds.) Il contributo delle analisi archeometriche allo studio delle ceramiche grezza e comuni. Bologne, 246-250.

Vendrell-Saz M, Pradell T, García-Vallès M T, Molera J (1997b) Producció i difusió de la ceràmica grisa a Catalunya durant l'Edat Mitjana, La ceràmica medieval catalana. El monument, document. Quaderns científics i tècnics 9. Barcelona, Diputació de Barcelona, 263-272.

Whitbread I K (1986) The characterization of argillaceous inclusions in ceramic thin sections. Archaeometry 28: 79-88 
FIGURES AND TABLES
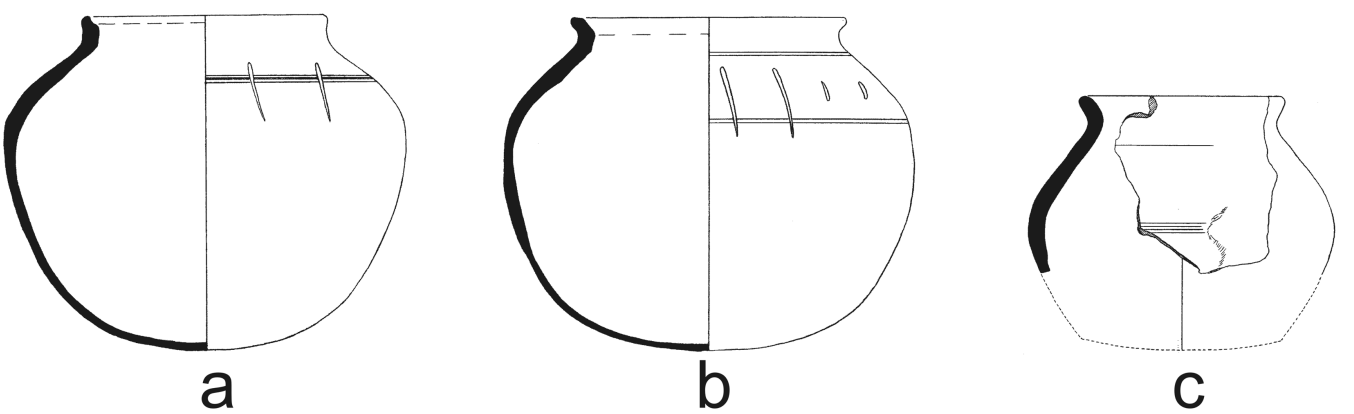

)

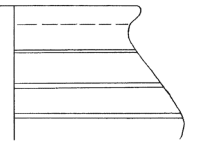

d

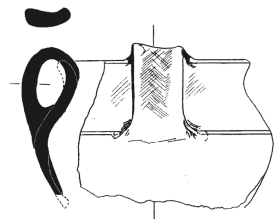

g
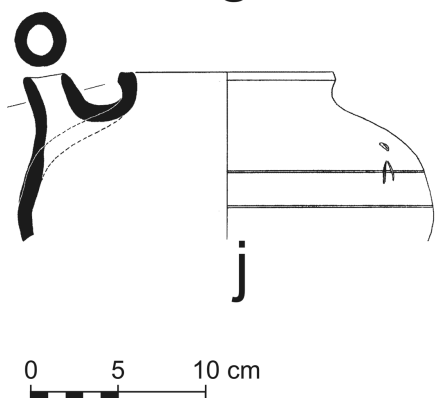

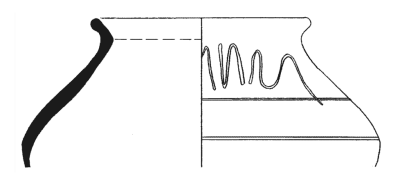

e
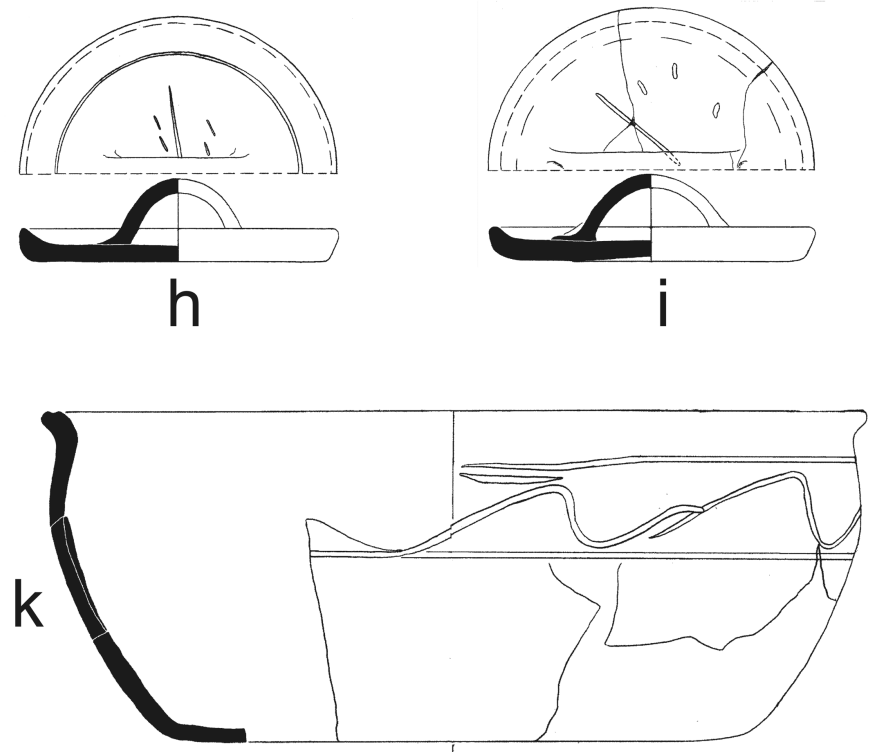

Fig. 1. Illustrations of greyware pottery vessels from the Medieval production site of Cabrera D'Anoia. Ollas (a-e), casserole (f), water jar (g), lids (h-i), and particular water jar with a cylindrical spout, known in written sources as cannata (j). 


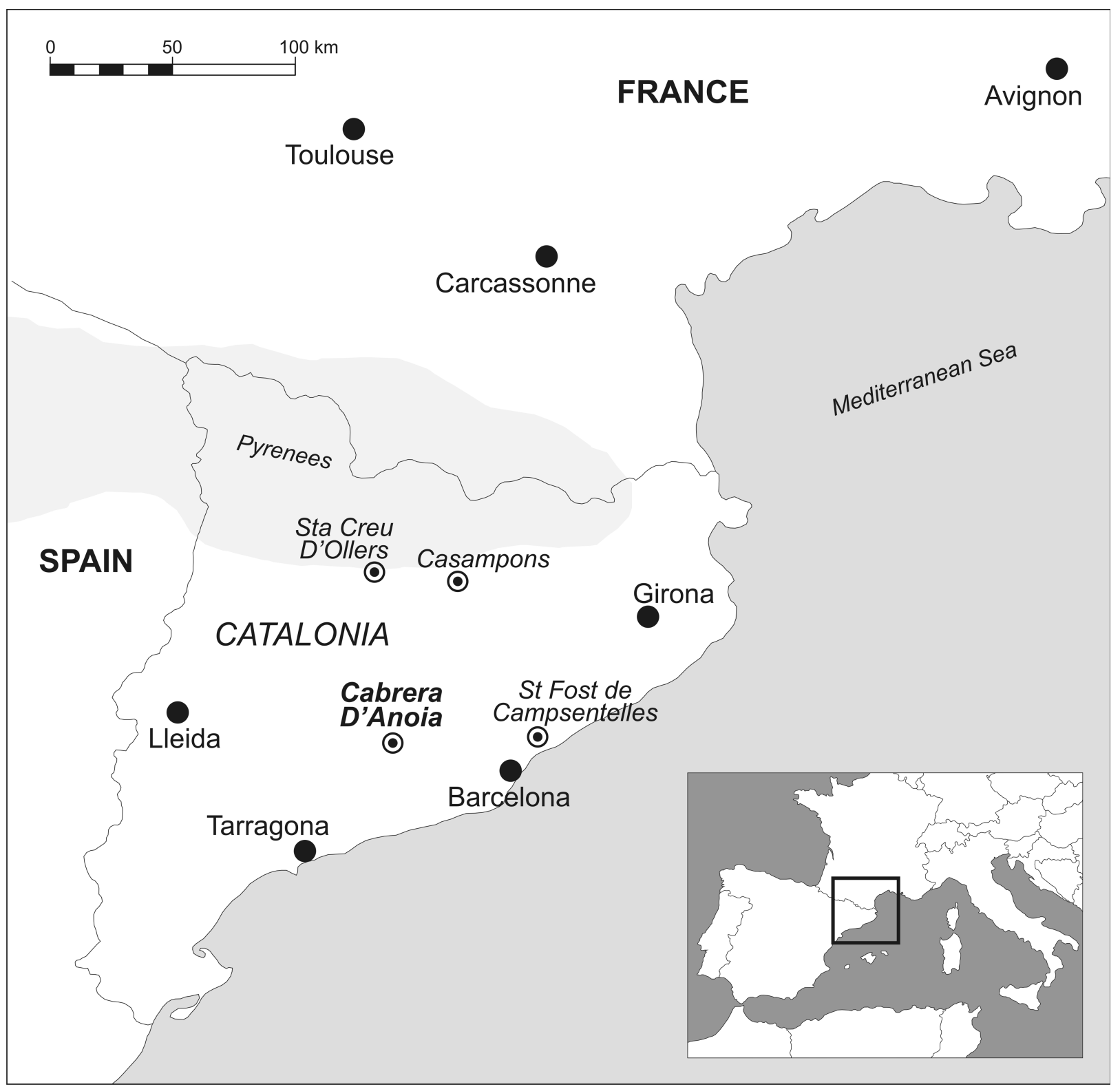

Fig. 2. Location of the Medieval pottery workshop of Cabrera D'Anoia. 


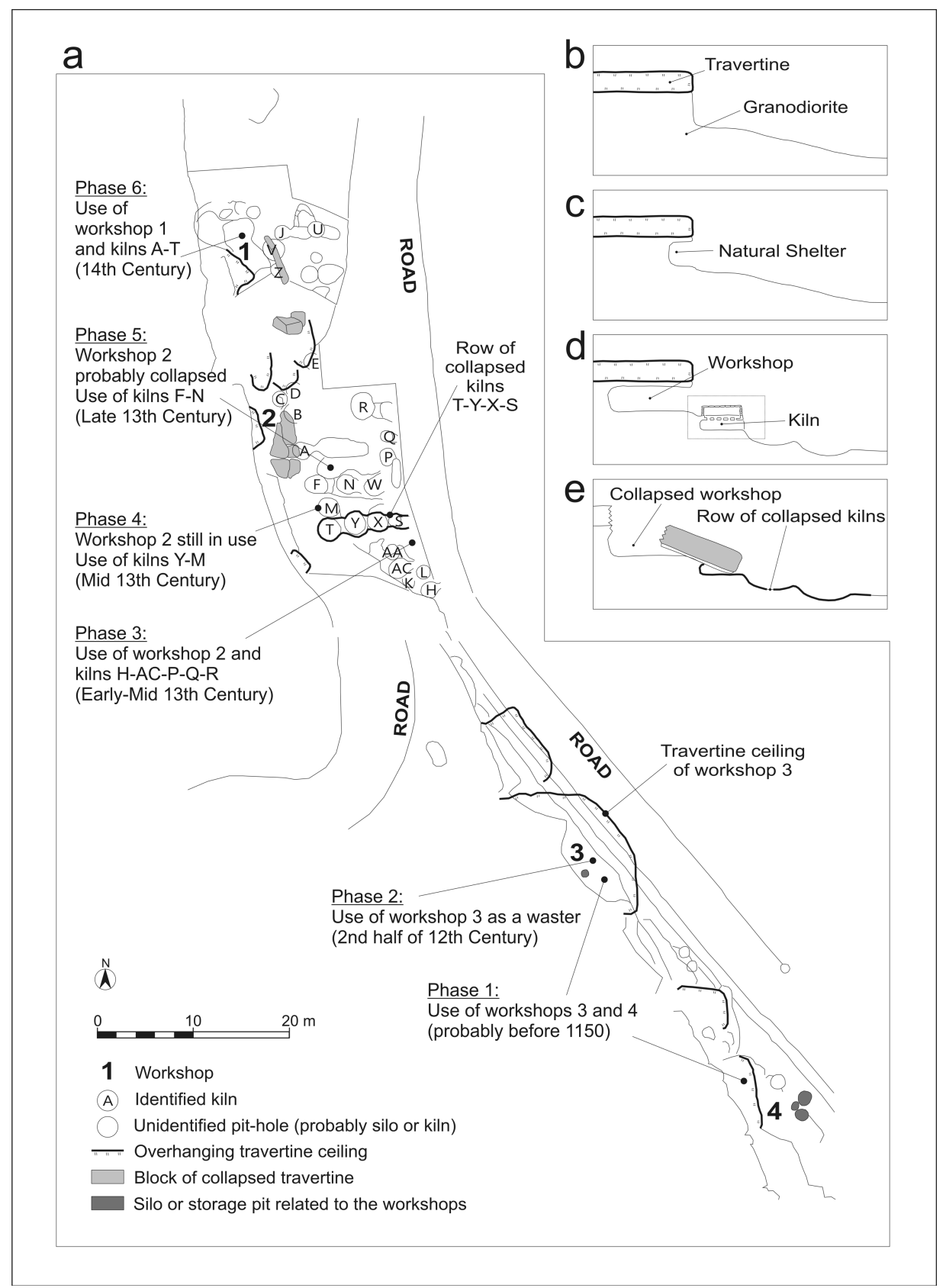

Fig. 3. Outline of the Medieval pottery workshop of Cabrera D'Anoia with interpreted phases and features (a). Exploitation of natural geological configuration of the landscape to establish workshops and kiln sites, that were subsequently abandoned $(\mathrm{b}-\mathrm{e})$. 


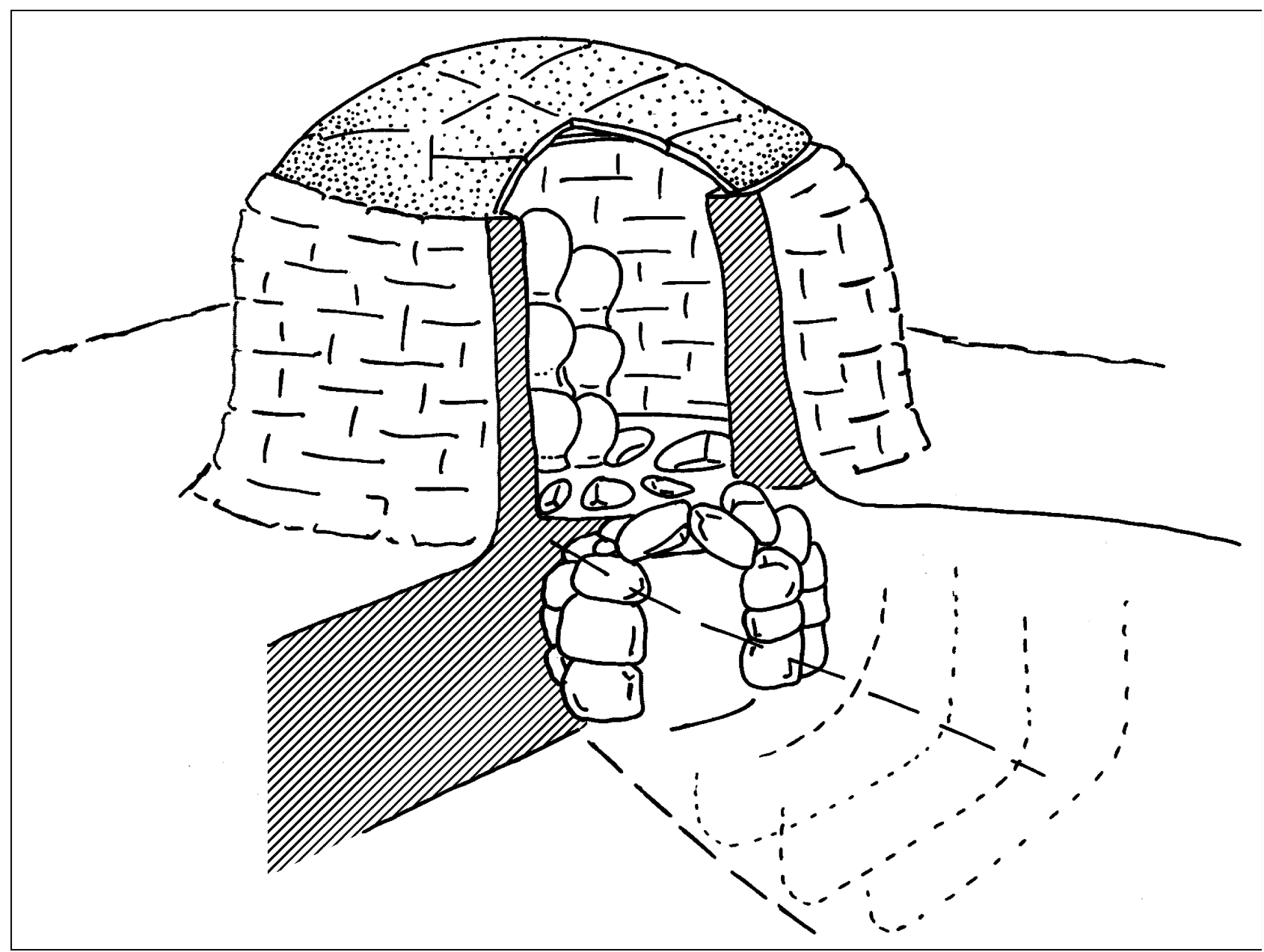

Fig. 4. Reconstruction of updraft double-chambered kiln type used at Cabrera D’Anoia (Travé 2009, 26). 

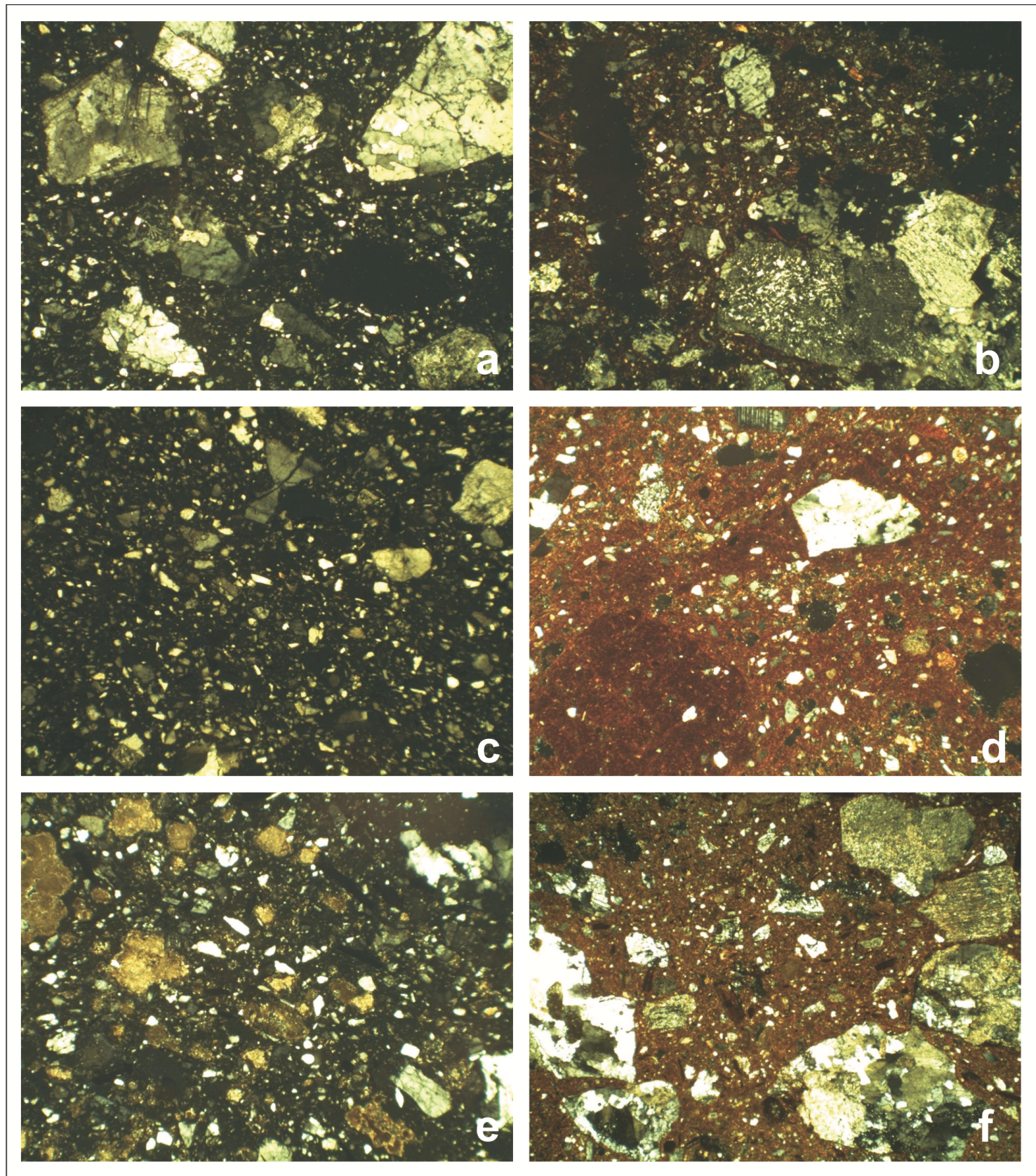

Fig. 5. Photomicrographs the petrographic fabric groups identified within the 100 Medieval greyware pottery sherds analysed from Cabrera D'Anoia in this study. Coarse Granitic Fabric (a, b), Fine Granitic Fabric (c), Coarse Granitic with Clay Pellets Fabric (d), Coarse Granitic with Calcite Fabric (e), relic coil feature picked out by orientation of inclusions in sample CDA026 of the Coarse granitic with Calcite Fabric. All images captured in crossed polars. Image width $=3 \mathrm{~mm}$, except $(\mathrm{f})=6 \mathrm{~mm}$. 


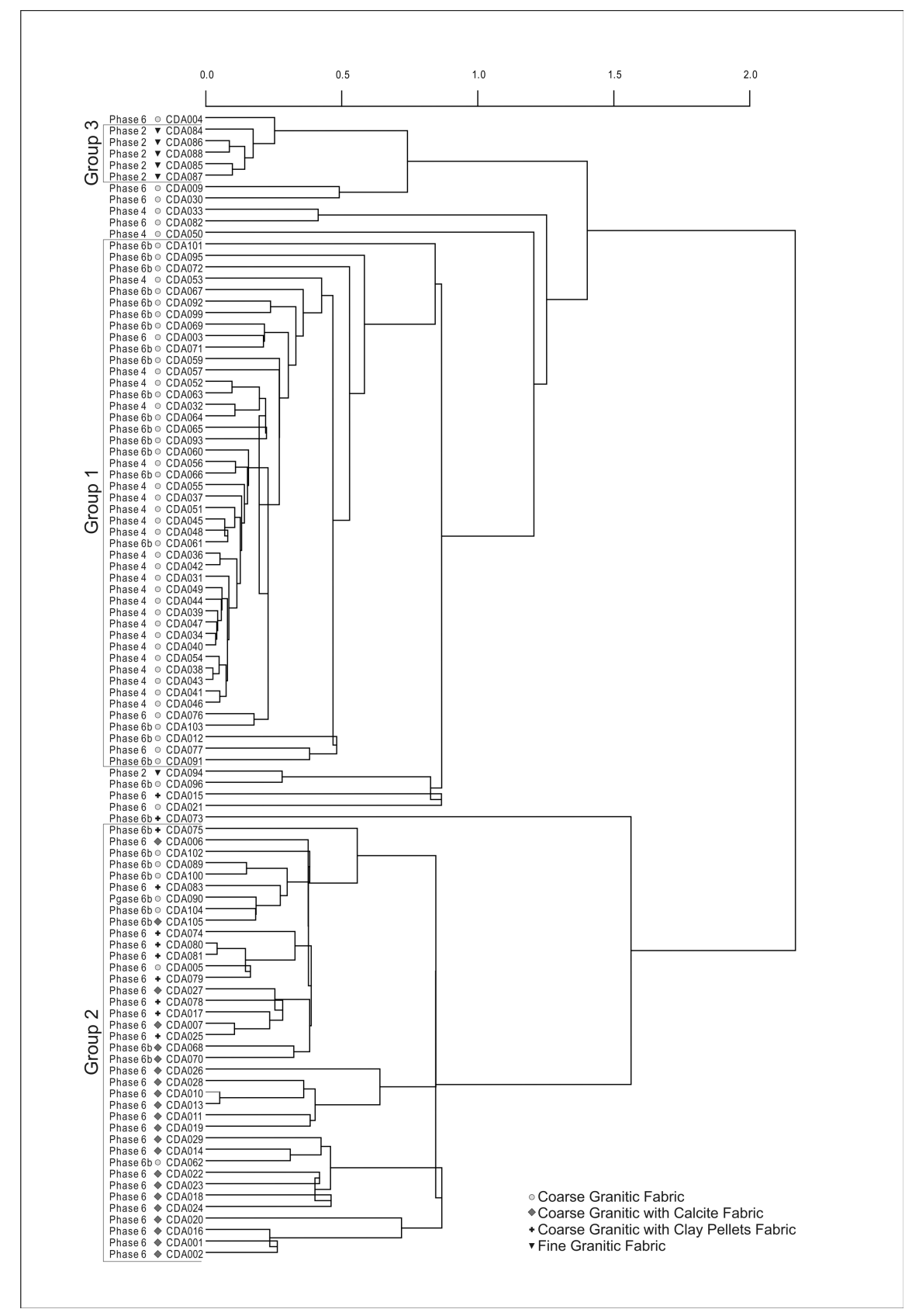

Fig. 6. Hierarchical cluster analysis dendrogram of the log-transformed multivariate geochemical data obtained by XRF analysis of the 100 Medieval greyware pottery sherds from Cabrera D'Anoia in this study. HCA was performed using Ward's method and squared elucidean distance. This indicates the existence of three main geochemical groups, that correlate well with the petrographic fabric classification of the same samples and the phase of the workshop from which they originated. 


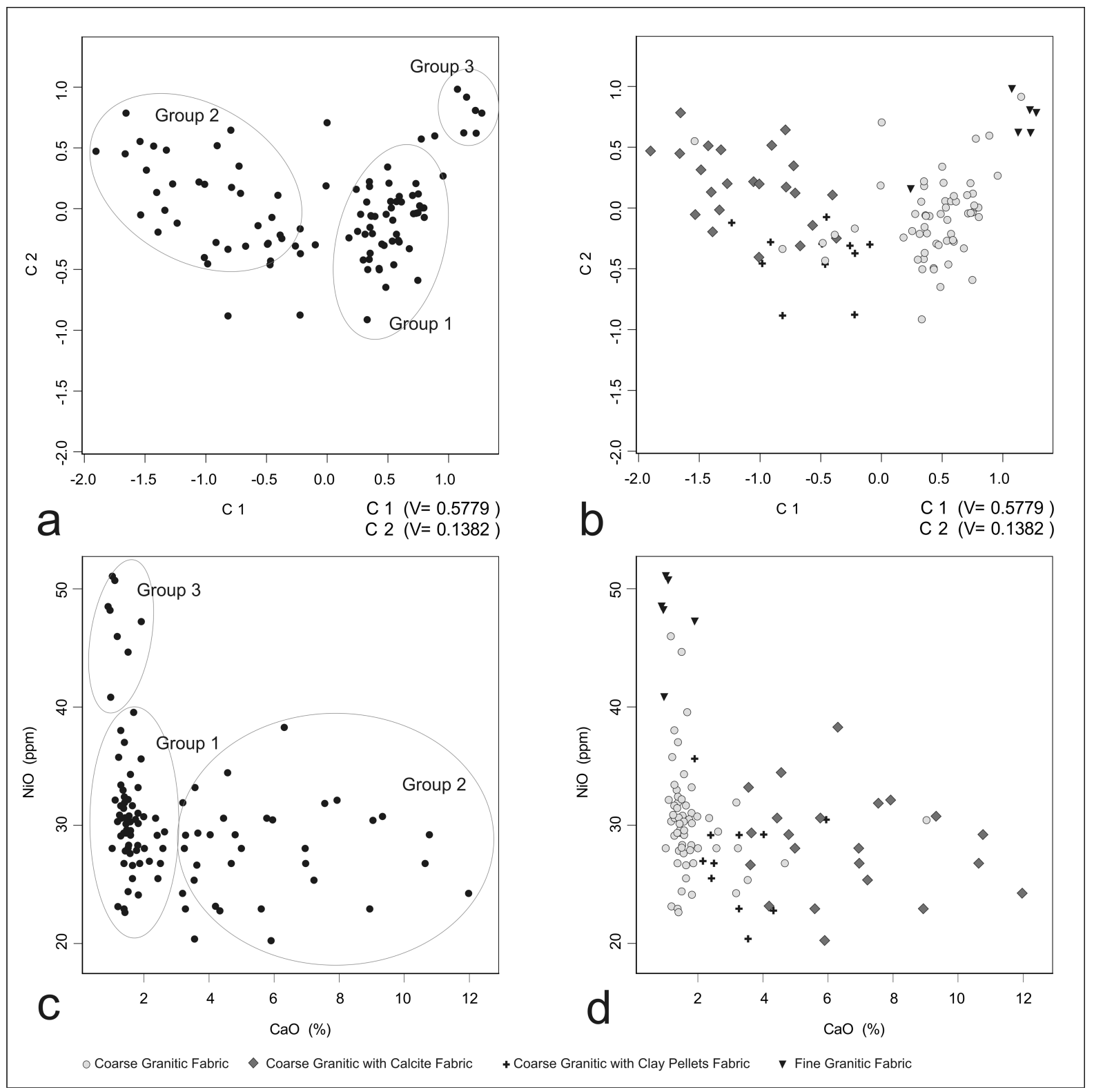

Fig. 7. Scatterplots of principal components analysis of the multivariate geochemical data obtained by XRF analysis of the 100 Medieval greyware pottery sherds from Cabrera D'Anoia in this study. and scatterplots of specific elements. Principal component 1 versus principal component 2 (a), principal component 1 versus principal component 2 with petrographic fabric classification indicated (b), concentration of $\mathrm{CaO}$ versus $\mathrm{NiO}$ (c), concentration of $\mathrm{CaO}$ versus $\mathrm{NiO}$ with petrographic fabric classification indicated (d). 


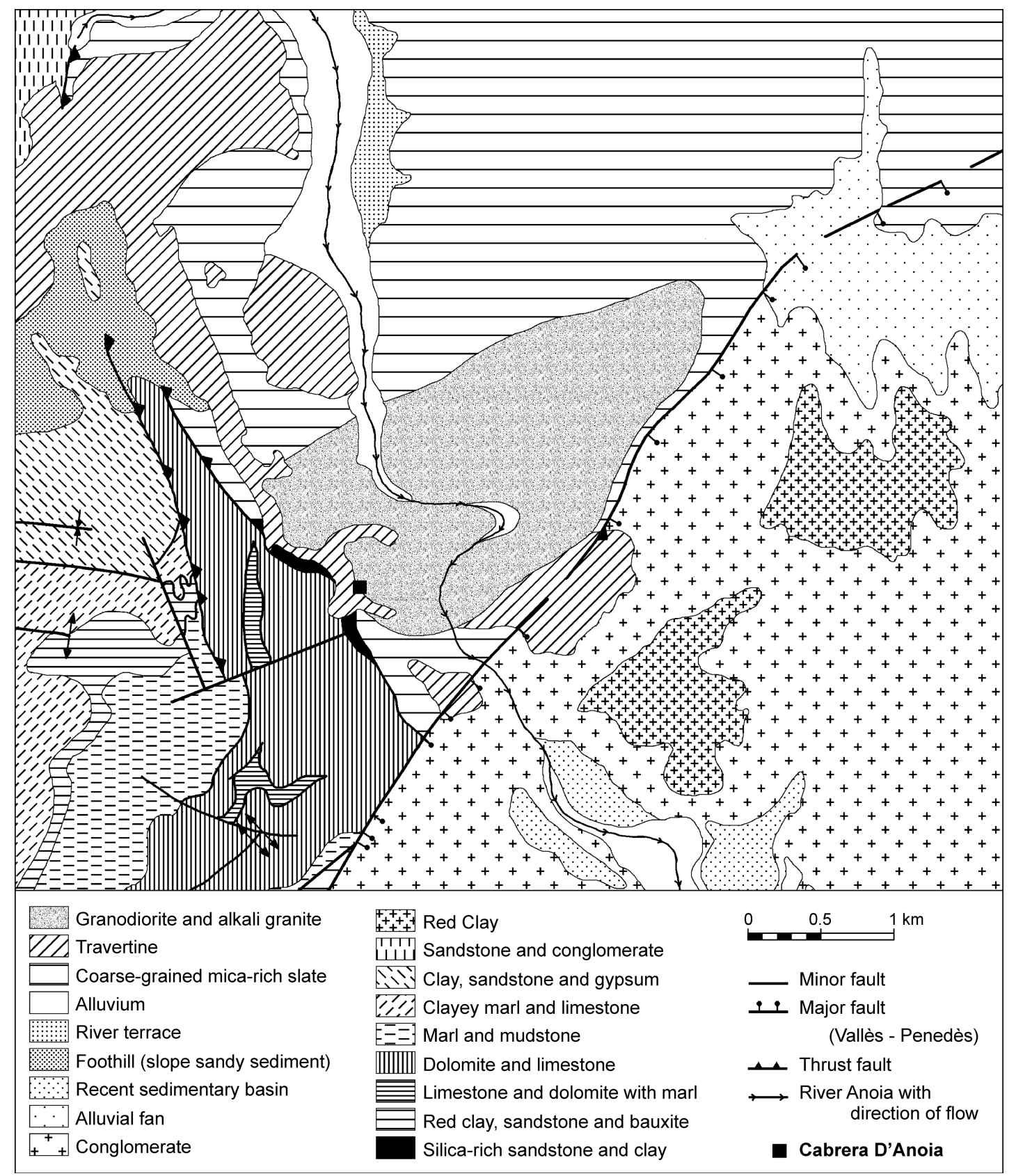

Fig. 8. Geological map of the landscape surrounding Cabrera D'Anoia. 


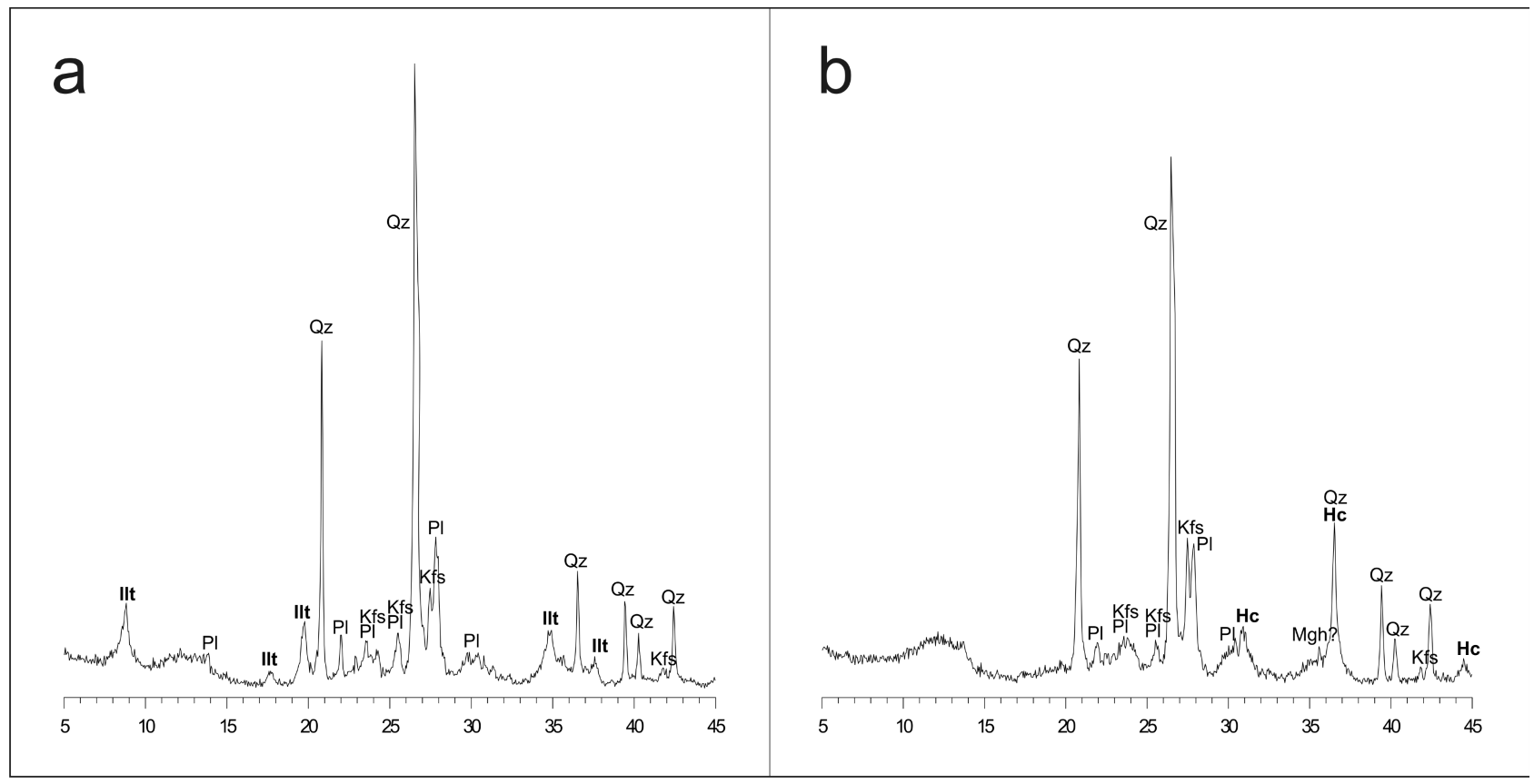

Fig. 9. X-Ray diffractograms of two greyware pottery sherds of the Coarse Granitic Fabric/Geochemical Group 1 from Cabrera D'Anoia with mineral phases that are indicative of firing temperature. Sample CDA012 containing the clay mineral illite that is suggestive of firing below c. $800^{\circ} \mathrm{C} \mathrm{(a),} \mathrm{sample} \mathrm{CDA043} \mathrm{without} \mathrm{illite,} \mathrm{and} \mathrm{with} \mathrm{significant}$ quantities of hercynite that forms above c. $900^{\circ} \mathrm{C}$ during firing. 
Table 1. Details of 100 Medieval greyware pottery sherds analysed from Cabrera D'Anoia in this study, including size, shape classification and the phase of the workshop from which they were selected. The samples are arranged according to their compositional classification based on thin section petrography and geochemistry. Phase $2=12$ th century AD, Phase $4=$ mid 13 th century AD, Phase $6=$ late 13 th century AD, Phase $6 b=$ mid 14 th century AD.

\begin{tabular}{|c|c|c|c|c|c|c|c|}
\hline Sample & Phase & Petrographic Fabric & $\begin{array}{l}\text { Geochemical } \\
\text { Group }\end{array}$ & Sample & Phase & Petrographic Fabric & $\begin{array}{l}\text { Geochemical } \\
\text { Group }\end{array}$ \\
\hline CA003 & Phase 6a & Coarse Granitic Fabric & 1 & CA091 & Phase $6 \mathrm{~b}$ & Coarse Granitic Fabric & 1 \\
\hline CA004 & Phase 6a & Coarse Granitic Fabric & outlier & CA092 & Phase $6 \mathrm{~b}$ & Coarse Granitic Fabric & 1 \\
\hline CA005 & Phase 6a & Coarse Granitic Fabric & 2 & CA093 & Phase $6 b$ & Coarse Granitic Fabric & 1 \\
\hline CA009 & Phase 6a & Coarse Granitic Fabric & outlier & CA095 & Phase $6 b$ & Coarse Granitic Fabric & 1 \\
\hline CA012 & Phase 6a & Coarse Granitic Fabric & 1 & CA096 & Phase $6 \mathrm{~b}$ & Coarse Granitic Fabric & outlier \\
\hline CA021 & Phase 6a & Coarse Granitic Fabric & outlier & CA099 & Phase $6 b$ & Coarse Granitic Fabric & 1 \\
\hline CA030 & Phase 6a & Coarse Granitic Fabric & outlier & CA100 & Phase $6 b$ & Coarse Granitic Fabric & 2 \\
\hline CA031 & Phase 4 & Coarse Granitic Fabric & 1 & CA101 & Phase 6b & Coarse Granitic Fabric & 1 \\
\hline CA032 & Phase 4 & Coarse Granitic Fabric & 1 & CA102 & Phase $6 b$ & Coarse Granitic Fabric & 2 \\
\hline CA033 & Phase 4 & Coarse Granitic Fabric & outlier & CA103 & Phase 6b & Coarse Granitic Fabric & 1 \\
\hline CA034 & Phase 4 & Coarse Granitic Fabric & 1 & CA104 & Phase 6b & Coarse Granitic Fabric & 2 \\
\hline CA036 & Phase 4 & Coarse Granitic Fabric & 1 & CA001 & Phase 6a & C. G. with Calcite Fabric & 2 \\
\hline CA037 & Phase 4 & Coarse Granitic Fabric & 1 & CA002 & Phase 6a & C. G. with Calcite Fabric & 2 \\
\hline CA038 & Phase 4 & Coarse Granitic Fabric & 1 & CA006 & Phase 6a & C. G. with Calcite Fabric & 2 \\
\hline CA039 & Phase 4 & Coarse Granitic Fabric & 1 & CA007 & Phase 6a & C. G. with Calcite Fabric & 2 \\
\hline CA040 & Phase 4 & Coarse Granitic Fabric & 1 & CA010 & Phase 6a & C. G. with Calcite Fabric & 2 \\
\hline CA041 & Phase 4 & Coarse Granitic Fabric & 1 & CA011 & Phase 6a & C. G. with Calcite Fabric & 2 \\
\hline CA042 & Phase 4 & Coarse Granitic Fabric & 1 & CA013 & Phase 6a & C. G. with Calcite Fabric & 2 \\
\hline CA043 & Phase 4 & Coarse Granitic Fabric & 1 & CA014 & Phase 6a & C. G. with Calcite Fabric & 2 \\
\hline CA044 & Phase 4 & Coarse Granitic Fabric & 1 & CA016 & Phase 6a & C. G. with Calcite Fabric & 2 \\
\hline CA045 & Phase 4 & Coarse Granitic Fabric & 1 & CA018 & Phase 6a & C. G. with Calcite Fabric & 2 \\
\hline CA046 & Phase 4 & Coarse Granitic Fabric & 1 & CA019 & Phase 6a & C. G. with Calcite Fabric & 2 \\
\hline CA047 & Phase 4 & Coarse Granitic Fabric & 1 & CA020 & Phase 6a & C. G. with Calcite Fabric & 2 \\
\hline CA048 & Phase 4 & Coarse Granitic Fabric & 1 & CA022 & Phase $6 \mathrm{a}$ & C. G. with Calcite Fabric & 2 \\
\hline CA049 & Phase 4 & Coarse Granitic Fabric & 1 & CA023 & Phase $6 \mathrm{a}$ & C. G. with Calcite Fabric & 2 \\
\hline CA050 & Phase 4 & Coarse Granitic Fabric & outlier & CA024 & Phase 6a & C. G. with Calcite Fabric & 2 \\
\hline CA051 & Phase 4 & Coarse Granitic Fabric & 1 & CA026 & Phase 6a & C. G. with Calcite Fabric & 2 \\
\hline CA052 & Phase 4 & Coarse Granitic Fabric & 1 & CA027 & Phase $6 \mathrm{a}$ & C. G. with Calcite Fabric & 2 \\
\hline CA053 & Phase 4 & Coarse Granitic Fabric & 1 & CA028 & Phase $6 \mathrm{a}$ & C. G. with Calcite Fabric & 2 \\
\hline CA054 & Phase 4 & Coarse Granitic Fabric & 1 & CA029 & Phase 6a & C. G. with Calcite Fabric & 2 \\
\hline CA055 & Phase 4 & Coarse Granitic Fabric & 1 & CA068 & Phase $6 \mathrm{~b}$ & C. G. with Calcite Fabric & 2 \\
\hline CA056 & Phase 4 & Coarse Granitic Fabric & 1 & CA070 & Phase $6 \mathrm{~b}$ & C. G. with Calcite Fabric & 2 \\
\hline CA057 & Phase 4 & Coarse Granitic Fabric & 1 & CA105 & Phase $6 b$ & C. G. with Calcite Fabric & 2 \\
\hline CA059 & Phase $6 b$ & Coarse Granitic Fabric & 1 & CA015 & Phase $6 a$ & C. G. \& Clay Pellets Fabric & outlier \\
\hline
\end{tabular}




\begin{tabular}{|c|c|c|c|c|c|c|c|}
\hline CA060 & Phase $6 b$ & Coarse Granitic Fabric & 1 & CA017 & Phase $6 \mathrm{a}$ & C. G. \& Clay Pellets Fabric & 2 \\
\hline CA061 & Phase $6 \mathrm{~b}$ & Coarse Granitic Fabric & 1 & CA025 & Phase $6 \mathrm{a}$ & C. G. \& Clay Pellets Fabric & 2 \\
\hline CA062 & Phase $6 b$ & Coarse Granitic Fabric & 2 & CA073 & Phase $6 \mathrm{~b}$ & C. G. \& Clay Pellets Fabric & outlier \\
\hline CA063 & Phase $6 \mathrm{~b}$ & Coarse Granitic Fabric & 1 & CA074 & Phase $6 a$ & C. G. \& Clay Pellets Fabric & 2 \\
\hline CA064 & Phase $6 b$ & Coarse Granitic Fabric & 1 & CA075 & Phase $6 \mathrm{a}$ & C. G. \& Clay Pellets Fabric & 2 \\
\hline CA065 & Phase $6 b$ & Coarse Granitic Fabric & 1 & CA078 & Phase $6 \mathrm{a}$ & C. G. \& Clay Pellets Fabric & 2 \\
\hline CA066 & Phase $6 \mathrm{~b}$ & Coarse Granitic Fabric & 1 & CA079 & Phase $6 \mathrm{a}$ & C. G. \& Clay Pellets Fabric & 2 \\
\hline CA067 & Phase $6 \mathrm{~b}$ & Coarse Granitic Fabric & 1 & CA080 & Phase $6 a$ & C. G. \& Clay Pellets Fabric & 2 \\
\hline CA069 & Phase $6 \mathrm{~b}$ & Coarse Granitic Fabric & 1 & CA081 & Phase 6a & C. G. \& Clay Pellets Fabric & 2 \\
\hline CA071 & Phase $6 \mathrm{~b}$ & Coarse Granitic Fabric & 1 & CA083 & Phase $6 \mathrm{a}$ & C. G. \& Clay Pellets Fabric & 2 \\
\hline CA072 & Phase $6 \mathrm{~b}$ & Coarse Granitic Fabric & 1 & CA084 & Phase 2 & Fine Granitic Fabric & 3 \\
\hline CA076 & Phase 6a & Coarse Granitic Fabric & 1 & CA085 & Phase 2 & Fine Granitic Fabric & 3 \\
\hline CA077 & Phase 6a & Coarse Granitic Fabric & 1 & CA086 & Phase 2 & Fine Granitic Fabric & 3 \\
\hline CA082 & Phase 6a & Coarse Granitic Fabric & outlier & CA087 & Phase 2 & Fine Granitic Fabric & 3 \\
\hline CA089 & Phase $6 b$ & Coarse Granitic Fabric & 2 & CA088 & Phase 2 & Fine Granitic Fabric & 3 \\
\hline CA090 & Phase $6 b$ & Coarse Granitic Fabric & 2 & CA094 & Phase $6 b$ & Fine Granitic Fabric & outlier \\
\hline
\end{tabular}


Table 2. Summary of the main geochemical characteristics of the compositional groups of Medieval greyware pottery from the pottery producing centre of Cabrera D'Anoia established in this study. The abundance of major and minor elements expressed as percentage weight (\%wt) and trace elements as parts per million (ppm). Standard deviation is given in parentheses.

\begin{tabular}{|c|c|c|c|c|c|c|c|c|c|c|c|c|c|}
\hline \multirow{2}{*}{$\frac{(\% w t)}{\mathbf{N a}_{2} \mathbf{O}}$} & \multicolumn{2}{|c|}{ GROUP 1} & \multicolumn{2}{|c|}{ GROUP 2} & \multicolumn{2}{|c|}{ GROUP 3} & \multirow{2}{*}{$\frac{\int^{(p p m}}{\mathbf{N i}}$} & \multicolumn{2}{|c|}{ GROUP 1} & \multicolumn{2}{|c|}{ GROUP 2} & \multicolumn{2}{|c|}{ GROUP 3} \\
\hline & 1.38 & $(0.05)$ & 1.19 & (0.09) & 0.66 & $(0.00)$ & & 23 & $(5.16)$ & 22 & $(8.60)$ & 38 & (8.64) \\
\hline MgO & 1.57 & $(0.02)$ & 2.26 & $(0.21)$ & 1.66 & $(0.02)$ & $\mathbf{C u}$ & 14 & $(9.80)$ & 13 & (24.53) & 30 & (20.80) \\
\hline $\mathrm{Al}_{2} \mathrm{O}_{3}$ & 16.52 & $(0.35)$ & $\begin{array}{r}16.3 \\
1\end{array}$ & (0.66) & 18.81 & $(0.68)$ & $\mathbf{Z n}$ & 76 & (43.87) & 73 & (56.97) & 124 & (60.56) \\
\hline $\mathrm{SiO}_{2}$ & 68.22 & $(1.29)$ & $\begin{array}{r}60.6 \\
7\end{array}$ & (17.69) & 65.32 & (1.81) & $\mathbf{G a}$ & 21 & (1.08) & 19 & (2.71) & 23 & $(0.24)$ \\
\hline $\mathrm{P}_{2} \mathrm{O}_{5}$ & 0.08 & $(0.00)$ & 0.10 & $(0.00)$ & 0.12 & $(0.00)$ & $\mathbf{R b}$ & 119 & (102.67) & 128 & $(237.50)$ & 139 & $(43.60)$ \\
\hline $\mathbf{K}_{2} \mathbf{O}$ & 3.09 & $(0.08)$ & 3.90 & (0.19) & 3.50 & $(0.11)$ & $\mathrm{Sr}$ & 151 & (239.09) & 190 & (403.79) & 123 & (36.16) \\
\hline $\mathrm{CaO}$ & 1.52 & $(0.07)$ & 5.33 & (6.55) & 0.98 & $(0.00)$ & $\mathbf{Y}$ & 36 & (8.77) & 30 & $(6.79)$ & 36 & (1.60) \\
\hline $\mathrm{TiO}_{2}$ & 0.72 & $(0.00)$ & 0.61 & $(0.00)$ & 0.91 & $(0.00)$ & $\mathbf{Z r}$ & 257 & (424.81) & 178 & (662.16) & 251 & (65.84) \\
\hline MnO & 0.08 & $(0.00)$ & 0.06 & $(0.00)$ & 0.09 & $(0.00)$ & $\mathbf{N b}$ & 17 & $(0.75)$ & 15 & $(0.82)$ & 20 & $(0.56)$ \\
\hline $\mathrm{Fe}_{2} \mathrm{O}_{3}$ & 5.38 & (0.09) & 5.10 & (0.13) & 6.89 & $(0.08)$ & $\mathbf{B a}$ & 563 & (2071.89) & 568 & (3532.42) & 522 & $\begin{array}{r}(488.5 \\
6)\end{array}$ \\
\hline (ppm) & & & & & & & $\mathrm{Ce}$ & 76 & (82.15) & 64 & (97.12) & 90 & $(46.80)$ \\
\hline V & $\begin{array}{r}104,0 \\
0\end{array}$ & $(45.05)$ & $\begin{array}{r}87,0 \\
0\end{array}$ & (55.11) & $\begin{array}{r}125,0 \\
0\end{array}$ & (18.56) & $\mathbf{P b}$ & 26 & (7.54) & 24 & (24.90) & 29 & $(1.76)$ \\
\hline $\mathrm{Cr}$ & 84,00 & $\begin{array}{r}(242.39 \\
)\end{array}$ & $\begin{array}{r}65,0 \\
0\end{array}$ & (146.64) & 88,00 & (30.16) & Th & 14 & $(2.05)$ & 14 & $(2.56)$ & 16 & $(0.96)$ \\
\hline
\end{tabular}

